\title{
An Environmental Impact Assessment of Sewage Pollution in Madurai District
}

\author{
J.S.Amarnath, U. Sridevi \\ Department of Agricultural Economics, Agricultural College and Research Institute, Tamil Nadu Agricultural University \\ Madurai, Tamil Nadu, India
}

\begin{abstract}
The study was conducted in Madurai district of Tamil Nadu to study the Environmental Impact Assessment of sewage pollution. The study revealed that the decline in crop production was directly related with the pollution intensity. The averting or defensive expenditure for drinking water and irrigation water included obtaining protected water, getting water from non-polluted areas, boiling the water and purchase of water filters. The agricultural damage function related the value of agricultural damages to averting expenditure of land and irrigation water and quality indices of land and water quality.Contingent valuation study revealed that the proportion of farmers WTP was higher in seriously affected category with 85.71 per cent study area and in low affected category, it was 28.57 per centwhich revealed that the willingness to pay varied according to pollution intensity. The amount of WTP was also higher for seriously affected farmers with Rs.1800 per year each in study area which was due to higher pollution intensity prevailing in these farms. Seriously affected farmers were interested and willing to pay whatever they were able to pay which might be due to high pollution prevailed in that category. The proportion of compensation was lower in seriously affected farms since the farmers in this category felt that the compensation principle would not be practical and time consuming. In seriously affected farms, household size and drinking water quality had positive influence on WTP. Age and Green index had negative influence on WTP. In low affected farms, household head's education, household size and occupation dummy had positive relationship with the willingness to pay while green index had negative influence on WTP.
\end{abstract}

Keywords- Averting or defensive expenditure, Agricultural damage function, Contingent valuation, Willingness to Pay, Willingness to Accept Compensation.

\section{INTROUCTION}

In Madurai district, sewage treatment plants are located at two regions of Avaniyapuram and Sakkimangalam. In these regions, sewage pollution affected the water resources, land, human and livestock. The negative externalities included contamination of ground water, reduction in soil fertility, reduction in cropped area, socio-economic consequences and health problems for both human beings and animals. Hence it was chosen purposively to study the impact of sewage pollution. In this juncture, no prior in depth scientific study has been taken up in the study area to assess the impact of sewage pollution. Many prior studies carried out in the district on sewage pollution were either partial, while examining the externalities associated with the said pollution or had studied the effects without any attempt on tangible value assessment.Hence an environmental impact assessment of sewage pollution was carried out in Avaniyapuram study area of Madurai district and the results are presented in this article.

\section{METHODOLOGY}

Madurai district was selected purposively for the study since it faces sewage problem due to location of Sewage Treatment Plants. Among the thirteen blocks of the district, Thiruparangudaram block and Madurai East block are affected by sewage pollution due to location ofsewage treatment plants in these blocks. Based on the intensity of the pollution as evinced from the electrical conductivity of irrigation water, the villages were classified into two categories namely seriously affected and low affected (Table 1). In Thiruparangudaram block, Avaniyapuramvillage was selected for seriously affected category purposively whereas another village namely Kaluvangulam was selected for low affected and Paraipatty village was selected for non-affected area. Then from each category, 35 farmers were selected at random.Thus the sample size constituted 105 farmers. 
Table.1: Electrical conductivity of irrigation water of study area

\begin{tabular}{|l|l|l|l|}
\hline S.No & \multicolumn{1}{|c|}{ Village } & \multicolumn{1}{|c|}{$\begin{array}{c}\text { Criteria } \\
\text { EC } \\
(\text { millimhos/cm) }\end{array}$} & Classification \\
\hline I & Avaniyapuram & 7.50 & $\begin{array}{l}\text { Seriously } \\
\text { affected }\end{array}$ \\
\hline II & Kaluvangulam & 2.00 & Low affected \\
\hline III & Paraipatty & 0.60 & Non affected \\
\hline
\end{tabular}

Source: Department of Agriculture- AvaniyapuramMadurai district 2015.

\section{ENVIRONMENTAL VALUATION TECHNIQUES}

The following environmental valuationtechniques were employed for the analysis.

\section{Production Change Technique}

The production change technique involved output ' $q$ ' measurable cases which is sold in market with price 'p'. The economic value of the change in resource supply is the value of the production change that would accompany it at constant input of other factors. In the present study, the changes in crop production and animal husbandry production were analysed between seriously affected farms and low affected farms with non- affected farms.

\section{Damage Functions}

The damage function is one which links pollution(Q) to something people value like yield(Y)

The function can be written as

$\mathrm{Y}=\mathrm{f}(\mathrm{Q})$, if no averting inputs were used.

$\mathrm{Y}=\mathrm{f}(\mathrm{Q}, \mathrm{Z})$, if averting inputs were used.

where, $\mathrm{Z}$ - Averting inputs.

Damage function comes under the indirect valuation technique. This yield damage function might be either physical loss concerned with physical damage, or value damage function aimed at value of the damage. In the present study, agricultural value damage function was employed. In agricultural damage function, averting expenditure on land, averting expenditure for irrigation, land quality index, water quality index were included. The damage functions employed in the study are

YIELD $=\mathrm{f}$ (LAVEREXP, IAVEREXP, LANDQUAL, WATQUAL) $+\mu_{1}-$

Where,

YIELD $=\quad$ Yield damage in rupees per hectare

LAVEREXP = Expenditure on averting inputs for land in rupees per hectare
IAVEREXP $=$ Expenditure on averting inputs for irrigation water per hectare

LANDQUAL = An index for quality of land(poor1,average-2,good-3)

WATQUAL = An index for irrigation water quality -sum of taste (1-3), softness (1-3)

and healthiness(1-3):1-poor,2-average,3-good.

Agriculture value damage are computed as the difference in the value of each affected farm over the mean value of non-affected farms for each item of damage. Analyses are carried out for serious and low affected farms separately for both the types of damage function.

\section{Averting Expenditure models}

The averting expenditure approach realizes the fact that purchased inputs could be used to mitigate the effects of pollution. Thus the averting expenditure included the expenditure on mitigating efforts before pollution occurrence and investment on purchased inputs for reduction of deleterious effects after pollution occurrence (Cropper and Oates, 1992).This averting /defensive expenditure was identified for the study based on the above author view and also relevant to the damage incidences of water pollution.

\section{Contingent Valuation Technique}

Contingent Valuation approach is the most well-known, seeking personal valuations for increases or decreases in the quantity of some good or services, contingent upon a hypothetical market. It is a method of establishing a monetary value for a good or services by asking people what they are prepared to pay for it. This method seeks to determine a level of payment acceptable to most of people or to accept compensation for a degraded environment.This is the contingent and related valuation of welfare effects of environmental degradation. This involves a resource by putting a monetary value on the response of the people affected by the change in the state of the resource. This method is well suited to the valuation of a change in the status of the environment.Contingent valuation method is based on interviewing of WTP (Willingness to Pay) by the demanders, who reveal their preferences based on their income and other considerations. Contingent valuation method is applied essentially asking people what they are WTP for the benefit.

The contingent valuation technique has its basis from utility theory and two consumer surpluses of Hick's compensating and equivalent surpluses. This could be explained by considering an individual(farmer) with a fixed income ' $y$ ' and spending this income on ' $n$ ' different commodities denoted by vector ' $x$ ' with a price ' $p$ '. The individual also 
derives utility from consuming a non-rival public good denoted by ' $\mathrm{q}$ '. The individuals' decision problem would be of maximizing $u\left(x, q^{0}\right)$ subject to $p x-y=0$. Solving the first order condition of this problem would yield the demand function for private goods, $\mathrm{x}=\mathrm{x}(\mathrm{p}, \mathrm{q}, \mathrm{y})$. Substituting this derived demand for private good ' $x$ ' in the utility function, an indirect utility function is obtained, which is

$$
\mathrm{V}(\mathrm{p}, \mathrm{q}, \mathrm{y})=\mathrm{u}(\mathrm{x}(\mathrm{p}, \mathrm{q}, \mathrm{y}), \mathrm{q})
$$

Now, the farmer respondent is confronted with questions of

1. What would be his willingness to pay for provision of public good 'q', say better soil and water quality, from $\mathrm{q}^{0}$ to $\mathrm{q}^{1}$

2. Assuming soil and water quality could not be improved, how much compensation, the farmers would need from a third party, say Government, to be as well off as he or she would have been, had the soil and water quality had improved from $\mathrm{q}^{0}$ to $\mathrm{q}^{1}$

The answers to these questions lie in compensating and equivalent variation measures.

Considering the hike in public goods provision changes, the consumer's utility from $u^{0}=v\left(p, q^{0}, y\right)$ to $u^{1}=v$ $\left(p, q^{1}, y\right)$ where $u^{1} \geq u^{0}$, the compensating variation (denoted by $\mathrm{C}$ ) is defined as

$$
\mathrm{V}\left(\mathrm{p}, \mathrm{q}^{1}, \mathrm{y}-\mathrm{C}\right)=\mathrm{V}\left(\mathrm{p}, \mathrm{q}^{0}, \mathrm{y}\right)
$$

And equivalent variation denoted by $\mathrm{E}$ as

$$
\mathrm{V}\left(\mathrm{p}, \mathrm{q}^{1}, \mathrm{y}\right) \quad=\mathrm{V}\left(\mathrm{p}, \mathrm{q}^{0}, \mathrm{y}+\mathrm{E}\right)
$$

The compensating variation measure gives how much the consumer is willing to pay to move to a higher utility due to higher public good provision(willingness to pay). The equivalent variation needed for the consumer to forego the increase in public good provision (willingness to accept).

In the present study, double - dichotomous choice contingent valuation procedure was adopted since this valuation procedure was found to be asymptotically more efficient. This approach involved asking a respondent whether he or she is willing to pay a pre- chosen amount. If the answer is yes, the respondent is asked again as to whether he or she is willing to pay a pre - chosen higher amount. If the answer is no, the respondent is asked again as to whether he or she is willing to pay a pre - chosen lower amount. Specifically in the present study, after eliciting double - dichotomous responses from the respondents, an open ended maximum willingness to pay question was asked to get precise value.

Respondents were also given the value of monthly as well as annual contributions, since the former seemed to be smaller than the latter and might cause fallacies in perceptions. Respondents were then asked about their preferred mode of payment, which is an open-ended question. Respondents were further asked about the reduction in monthly expenditure to make his payment which would remind them of the 'real' world where income and budget constraints operated. The same procedure was adopted for the willingness to accept compensation elicitation.

WTP

$=$ f(AGE,HHED,HHSIZ,HHINC,IOCP,WATQUAL, GREEN, $)+\mu$

WTP - Willingness to pay of respondent in rupees

AGE - $\quad$ Age of respondents in years

HHED - Household heads education (sum of years in school and college)

HHSIZ - Household size in number of persons

IOCP - A dummy variable for occupation (1farmer,0-otherwise)

WATQUAL - Drinking water quality index (poor-1, moderate-2, good-3)

GREEN - An index capturing the concern of the respondent for environmental Quality (1- strongly agree, 2- agree, 3-undecided, 4disagree,5-strongly

disagree)

$\mu \quad$ - Random error term

\section{RESULT AND DISCUSSION} Valuation using different environmental valuation techniques

Various environmental externalities are valued by five different valuation techniques namely production change technique, damage functions, averting expenditure, hedonic models and contingent valuation techniques and the results are discussed in this section.

\section{Production change technique}

The environmental externalities might be positive or negative and the positive externalities would lead to increase in production while, the negative externalities would lead to decline in production. In the present study, since negative externalities were prevalent due to sewage pollution, the decline in crop and animal husbandry production was analyzed between non-affected and affected farms. Since this production decline was measurable, the production change technique was employed, valued at 2015 market prices and are presented in Table 2.

It could be seen from the table that the value of crop production decline due to sewage pollution was higher in seriously affected farms with Rs. 62583 per hectare in study area as compared with non-affected farms. It was lower in 
low affected farms with Rs. 30526 per hectare in study area. Thus this decline in crop production was directly related with the pollution intensity. The results also indicated that the decline in value of animal husbandry production was also influenced by pollution intensity even though the decline was marginal as compared to crop production decline.

Table.2: Value estimates of production decline

\begin{tabular}{|r|c|c|c|}
\hline \multirow{2}{*}{ Sl.No } & \multirow{2}{*}{ Particulars } & \multicolumn{2}{|c|}{ Avaniyapuram } \\
\cline { 3 - 4 } & & Serious & Low \\
\hline 1. & Crop (Rs /ha) & 62583 & 30526 \\
\hline 2. & $\begin{array}{c}\text { Animal } \\
\text { husbandry(Rs/farm) }\end{array}$ & 950 & 700 \\
\hline
\end{tabular}

\section{Averting or defensive expenditure on water}

The details of averting or defensive expenditure made on water for irrigation and drinking purposes of both Avaniyapuram farms are presented in Table 3. In the case of averting expenditure on water which included both irrigation and drinking water, the total averting or defensive expenditure was higher in seriously affected farms with Rs.2861 per family in study area respectively followed by low affected farms (Rs.1756 per family) in study area respectively which showed the direct relationship of this expenditure with pollution intensity. Thus the averting expenditure for irrigation water increased with increase in pollution intensity.

Table.3: Averting or defensive expenditure on irrigation and drinking water

(Rs./ family)

\begin{tabular}{|c|l|c|c|}
\hline \multirow{2}{*}{ Sl.No } & \multirow{2}{*}{ Particulars } & \multicolumn{2}{|c|}{ Avaniyapuram } \\
\cline { 3 - 4 } & & Serious & Low \\
\hline \multirow{2}{*}{ I } & Irrigation & & \\
water - & using & 755 & 550 \\
& Gypsum & $26.39)$ & $(31.32)$ \\
& Drinking & & \\
\hline \multirow{2}{*}{ II } & Water & & \\
\hline \multirow{2}{*}{ I } & Expenditure & & \\
& involved in & 350 & $\begin{array}{c}150 \\
\text { getting }\end{array}$ \\
& protected & $(12.23)$ & $(8.54)$ \\
& water. & & \\
\hline \multirow{2}{*}{ Ii } & Boiling & $\begin{array}{c}456 \\
(15.94)\end{array}$ & $\begin{array}{c}200 \\
(11.39)\end{array}$ \\
\hline \multirow{2}{*}{ Iii } & water & $\begin{array}{c}450 \\
(15.73)\end{array}$ & $\begin{array}{c}256 \\
(14.58)\end{array}$ \\
\hline
\end{tabular}

\begin{tabular}{|c|l|c|c|}
\hline iv & $\begin{array}{l}\text { Expenditure } \\
\text { involved in } \\
\text { getting } \\
\text { water from } \\
\text { non-polluted } \\
\text { areas }\end{array}$ & $\begin{array}{c}850 \\
(29.71)\end{array}$ & $\begin{array}{c}600 \\
(34.17)\end{array}$ \\
\hline & Total & $\begin{array}{c}2861 \\
(100.00)\end{array}$ & $\begin{array}{c}1756 \\
(100.00)\end{array}$ \\
\hline
\end{tabular}

(Figures in parentheses indicate per cent to total)

It could also be seen from the table that averting or defensive expenditure for drinking water included obtaining protected water, getting water from non-polluted areas, boiling the water and purchase of water filters. The analysis of averting or defensive expenditure for drinking water revealed that the seriously affected farmers incurred more expenditure in getting water from non-polluted areas (29.71 per cent to total expenditure in this category in study area ), followed by making boiled water (15.94 per cent) and thirdly with purchase of water filters (15.73 per cent in study area). The low affected farmers expended more with 34.17 per cent per cent in study area in getting water from non-polluted areas followed by purchase of water filters with 14.58 per cent in study area respectively and thirdly in making boiled water with 11.39 per cent in study area respectively to the total expenditure. Thus, it could be concluded from the above discussion that the affected farmers expended more in getting water from non-polluted areas followed by boiling water and purchase of water filters and also the said expenditure increased with increase in pollution intensity.

\section{Agricultural damage functions}

Cobb- Douglas multiple regression function was attempted for estimating agricultural damage in both categories of affected farms.

\section{Seriously affected farms}

The estimates of agricultural damage function for affected farms of study areais furnished in Table 4 and it could be observed from the table that the agricultural damages in these farms were highly influenced by land averting expenditure and water quality index at one per cent level, and land quality index at five per cent significance level.

It could be seen from the table that land based averting expenditure had positive influence on agricultural damage in these farms. This is in contrary with the logical reasoning of decrease in agriculture damage when there is an increase of averting expenditure and this phenomenon was due to the prevailing high pollution intensity in these farms. Hence, the present level of averting expenditure incurred at 
farmers' level was insufficient to counter the damage. Similarly land quality index and water quality index also had positive influence on agricultural damage due to highest soil pollution and water pollution prevailing in these farms. Thus in seriously affected farms, the agricultural damage could be reduced by undertaking more of land averting expenditure and by improving both land quality index and water quality index.

\section{Low affected farms}

The results of low affected farms of study area are presented in Table 4 and it could be seen from table that the agricultural damages in these farms were highly influenced by land averting expenditure and irrigation water averting expenditure and land quality index at one per cent significance level. One per cent increase in land averting expenditure, ceteris paribus, resulted in decrease of agricultural damage by 0.27 per cent from the mean level due to prevailing low pollution intensity in these farms. Similarly, one per cent increase in irrigation water averting expenditure, ceteris paribus, resulted in decrease of agricultural damage by 0.25 per cent from the mean level which was also due to prevailing low pollution intensity in these farms. On the other hand, land quality index had positive influence on agricultural damage in these farms. Thus the agricultural damage in low affected farms could be reduced by improving the land quality index.

Table.4: Estimates of agricultural damage functions of Avaniyapuram study area

\begin{tabular}{|c|l|r|r|}
\hline S.No. & \multicolumn{1}{|c|}{ Particulars } & Serious & \multicolumn{1}{c|}{ Low } \\
\hline 1. & $\begin{array}{l}\text { Yield damage in } \\
\text { rupees per hectare }\end{array}$ & 9.47 & 14.18 \\
\hline 2. & Constant & $0.14^{* *}$ & $-0.27^{* *}$ \\
\hline 3. & $\begin{array}{l}\text { Land averting } \\
\text { expenditure in } \\
\text { rupees per hectare } \\
\left(\mathrm{X}_{1}\right)\end{array}$ & $0.01^{\mathrm{NS}}$ & $-0.25^{* *}$ \\
\hline 4. & $\begin{array}{l}\text { Averting } \\
\text { expenditure for } \\
\text { irrigation water } \\
\left(\mathrm{X}_{2}\right)\end{array}$ & $0.05^{*}$ & $0.30^{* *}$ \\
\hline 5. & $\begin{array}{l}\text { Land quality index } \\
\left(\mathrm{X}_{3}\right)\end{array}$ & $0.03^{* *}$ & $-0.02^{\mathrm{NS}}$ \\
\hline 6. & $\begin{array}{l}\text { water quality } \\
\text { index }\left(\mathrm{X}_{4}\right)\end{array}$ & $\begin{array}{l}\text { Adjusted } \\
\text { Coefficient of } \\
\text { multiple } \\
\text { determination }\left(\mathrm{R}^{2}\right)\end{array}$ & 0.72 \\
\hline 7. & & \\
\hline
\end{tabular}

$*_{*}$ P $\leq 0.01$ (two tailed test), $*_{-} \mathrm{P} \leq 0.05$ (two tailed test) and NS - Not significant

\section{Contingent valuation}

\section{Willingness to Pay by affected farmers}

The willingness to pay (WTP) by affected farmers are presented in Table 5 . It could be seen from the table that the proportion of farmers willing to pay was higher in study area for seriously affected category with 85.71 per cent. On the other hand, in low affected farm category, the proportion of farmers willing to pay in study area was lower with 28.57 per cent which revealed that the willingness to pay increased with pollution intensity. The amount of WTP was also higher for seriously affected farmers with Rs. 1800 per year each in the study area, which was due to higher pollution intensity prevailing in these farms. The amount of WTP for low affected farmers was lower with Rs. 800 per year each in the study area which was due to lower pollution intensity prevailing in these farms.

In low affected category of study area, even though the farmers were able to pay Rs. 1500 per annum, their WTP were only 53.33 per cent of able to pay which might be due to less pollution intensity prevailed in that category. On the other hand, the seriously affected farmers WTP was as high as 81.82 per cent of ability to pay in study area. The preferred mode of payment was annual payment and was higher in both categories in both study areas as compared to monthly payment. These analyses showed that WTP was increased with pollution intensity.

Table.5: Willingness To Pay by affected farmers

\begin{tabular}{|c|l|c|c|}
\hline \multirow{2}{*}{ S.No } & \multirow{2}{*}{ Particulars } & \multicolumn{2}{|c|}{ Avaniyapuram } \\
\cline { 3 - 4 } & & Serious & Low \\
\hline 1. & $\begin{array}{l}\text { Willingness to } \\
\text { pay }\end{array}$ & & \\
\hline a. & Numbers(\%) & 85.71 & 28.57 \\
\hline b. & $\begin{array}{l}\text { Maximum per } \\
\text { annum (Rs) }\end{array}$ & 1800 & 800 \\
\hline c. & $\begin{array}{l}\text { Able to pay per } \\
\text { annum (Rs) }\end{array}$ & 2200 & 1500 \\
\hline 2. & $\begin{array}{l}\text { Mode of } \\
\text { payment }\end{array}$ & 17.14 & 22.86 \\
\hline a. & Month (in\%) & 82.86 & 77.14 \\
\hline b. & Annual (in\%) \\
\hline
\end{tabular}

Willingness to accept compensation by affected farmers The details of willingness to accept compensation is presented in Table 6. In this case, the proportion was higher for low affected farmers with 71.43 per cent of study area respectively. It was lower with 14.29 per cent for seriously 
affected farmers of the study area. The proportion of compensation was lower in seriously affected farms since the farmers in this category felt that the compensation principle would not be practical and time consuming. They wanted immediate solution since they were affected seriously. For both categories of farmers in both study areas, there was no limit in accepting compensation.

The contingent valuation technique employed in the study revealed the damage of seriously affected farmers at Rs. 1800 per annum and Rs. 800 for low affected farmers. The sewage pollution problem is being existed in the area for more than 8 years and hence the compensation amount worked out to Rs. 14,400 using this time span for seriously affected farmers and Rs. 6400 for low affected farmers.

Table.6: Willingness to accept compensation by affected farmers

\begin{tabular}{|c|l|c|c|}
\hline \multirow{2}{*}{ SI.No } & \multirow{2}{*}{ Particulars } & \multicolumn{2}{|c|}{ Avaniyapuram } \\
\cline { 3 - 4 } & & Serious & Low \\
\hline 1. & Number(\%) & 14.29 & 71.43 \\
\hline \multirow{2}{*}{2.} & $\begin{array}{l}\text { Willingness to } \\
\text { accept } \\
\text { compensation } \\
\text { (Rs/year) }\end{array}$ & No limit & $\begin{array}{c}\text { No } \\
\text { limit }\end{array}$ \\
\hline
\end{tabular}

Factors influencing Willingness to Pay

The factors influencing willingness to pay were studied using linear regression technique in affected farms. This analysis was done to prove that WTP estimate obtained was not a random number but a realistic estimate. The age of respondent, households head's education, household size, occupation dummy, water quality index, green index were included as regressors and the results are presented in Table 7.

\section{Seriously affected farmers}

The willingness to pay in this category of farms was influenced by age of the respondent, household size, occupation dummy and drinking water quality index. One year addition in age of the respondent, ceteris paribus, decreased the willingness to pay by Rs. 4.23 from the mean level and thus the age had negative influence to willingness to pay. The household size, if increased by one person, ceteris paribus, the willingness to pay increased by Rs.139.24 from the mean level and thus had positive influence.

The occupation dummy had negative influence over willingness to pay of seriously affected farmers, that are if the respondent not being a farmer alone and with subsidiary occupations increased, ceteris paribus, the willingness to pay decreased by Rs. 54.78 from the mean level. This negative relationship was obvious since this category of respondents (not being a farmer alone) had subsidiary or off-farm or non-farm income for making willingness to pay payments. Also, the farmer might not be interested in making payments since the pollution intensity was severe in this category of farms. The drinking water quality index, if increased by one per cent, ceteris paribus, the willingness to pay increased by Rs. 82.50 from the mean level. It had a positive influence with the WTP since increase in water quality index was associated with good land quality.

\section{Low affected farmers}

In low affected farms, household head's education, household size and occupation dummy had positive relationship with the willingness to pay. One year increase of household head's education, ceteris paribus, increased the willingness to pay by Rs 14.37 , from the mean level which had shown positive influence of education. The household size, if increased by one person, ceteris paribus, the willingness to pay increased by Rs.20.85 from the mean level and thus had positive influence.

Table.7: Estimates of factors influencing willingness to pay

\begin{tabular}{|c|l|c|c|}
\hline \multicolumn{4}{|c|}{ of Avaniyapuram study area } \\
\hline Sl.No & \multicolumn{1}{|c|}{ Particulars } & Serious & Low \\
\hline 1. & $\begin{array}{l}\text { Willingness to } \\
\text { pay in rupees } \\
(\mathrm{Y})\end{array}$ & & \\
\hline 2. & Constant & 560.58 & 44.72 \\
\hline 3. & $\begin{array}{l}\text { Age of } \\
\text { respondent in } \\
\text { years }\left(\mathrm{X}_{1}\right)\end{array}$ & $-4.23^{* *}$ & $1.20^{\mathrm{NS}}$ \\
\hline 4. & $\begin{array}{l}\text { Household } \\
\text { head's } \\
\text { education }\left(\mathrm{X}_{2}\right)\end{array}$ & $-3.58^{\mathrm{NS}}$ & $14.37^{* *}$ \\
\hline 5. & $\begin{array}{l}\text { Household size } \\
\text { in numbers } \\
\left(\mathrm{X}_{3}\right)\end{array}$ & $139.24^{*}$ & $20.85^{*}$ \\
\hline $6 .$. & $\begin{array}{l}\text { Occupation } \\
\text { dummy }\left(\mathrm{X}_{4}\right)\end{array}$ & $-54.78^{*}$ & $84.35^{*}$ \\
\hline 7. & $\begin{array}{l}\text { Water quality } \\
\text { index }\left(\mathrm{X}_{5}\right)\end{array}$ & $82.50^{*}$ & $-2.27^{\mathrm{NS}}$ \\
\hline 8. & $\begin{array}{l}\text { Green index } \\
\left(\mathrm{X}_{6}\right)\end{array}$ & $-27.94^{\mathrm{NS}}$ & $-1.94^{* *}$ \\
\hline 9. & $\begin{array}{l}\text { Adjusted } \\
\text { Coefficient of } \\
\text { multiple } \\
\text { determination } \\
\left(\mathrm{R}^{2}\right)\end{array}$ & - & 0.86 \\
\hline
\end{tabular}

$*_{-}$P $\leq 0.01$ (two tailed test), $*_{-} \mathrm{P} \leq 0.05$ (two tailed test) and NS - Not significant 
The occupation dummy had positive influence over willingness to pay of low affected farmers, that is if the respondent being a not farmer alone increased, ceteris paribus, the willingness to pay increased by 84.35 from the mean level. The occupation dummy in this category of farms had positive influence on WTP payments. This finding is in contrast with the result obtained for seriously affected farmers since in low affected farms, the pollution intensity was at low level. Hence farmers are much more interested in countering the damage and consequently resulted in more willingness to pay payment.

The green index had negative influence over willingness to pay of low affected farmers, The green index, if increased, then the perception of the individual for environmental concerns is increased from 'strongly agree' towards 'strongly disagree' which resulted in people being less green. Thus the green index if increased by one unit, ceteris paribus, the willingness to pay would be decreased by Rs.1.94 from the mean level. One could deduce from this exposition that people, who are 'green', are willing to pay more.

\section{CONCLUSIONS}

The decline in crop production was directly related with the pollution intensity. The decline in value of animal husbandry production was also influenced by pollution intensity even though the decline was marginal. The averting or defensive expenditure for drinking water and irrigation water included obtaining protected water, getting water from non-polluted areas, boiling the water and purchase of water filters. This expenditure was higher in seriously affected farms followed by low affected farms which showed the direct relationship of this expenditure with pollution intensity. Also, the affected farmers expended more in getting water from non-polluted areas followed by boiling water and purchase of water filters.

The agricultural damage function related the value of agricultural damages to averting expenditure of land and irrigation water and quality indices of land and water quality. The analysis revealed that in seriously affected farms of study area, the agricultural damage could be reduced by undertaking more of land averting expenditure and by improving both land quality index and water quality index. In low affected farms of study area, undertaking land averting expenditure and irrigation water averting expenditure decreased the agricultural damage which was due to prevailing low pollution intensity in these farms. Land quality index had positive influence on agricultural damage in these farms and hence the agricultural damage in these farms could be reduced byimproving the land quality index. The proportion of farmers WTP was higher in seriously affected category with 85.71 per cent study area and in low affected category, it was 28.57 per centwhich revealed that the willingness to pay varied according to pollution intensity. The amount of WTP was also higher for seriously affected farmers with Rs.1800 per year each in study area which was due to higher pollution intensity prevailing in these farms. Even though the amount of able to pay for low affected farmers was Rs. 1500 per annum, their WTP was only Rs. 800 per annum which might be due to low pollution intensity prevailed in that category. On the other hand, the seriously affected farmers WTP was as high as 81.82 per cent of able to pay in study area. Seriously affected farmers were interested and willing to pay whatever they were able to pay which might be due to high pollution prevailed in that category. The preferred mode of payment was annual payment among all affected farmers. The proportion of willingness to accept compensation was higher for low affected farmers with 71.43 per cent study area and it was 14.29 per cent for seriously affected farmers in study area. The proportion of compensation was lower in seriously affected farms since the farmers in this category felt that the compensation principle would not be practical and time consuming. They wanted immediate solution since they were affected seriously. For both categories of farmers in both study areas, there was no limit in accepting compensation.

In seriously affected farms, household size and drinking water quality had positive influence on WTP. Age and Green index had negative influence on WTP. In low affected farms, household head's education, household size and occupation dummy had positive relationship with the willingness to pay while green index had negative influence on WTP. All the positive and negative influence of various factors on WTP in both the affected farms had logical underpinnings and matched the theoretical expectations which proved that WTP estimate elicited from the respondent is a realistic estimate.

\section{Policy implications}

The study revealed that the sewage pollution resulted in increased averting or defensive expenditure for irrigation water and drinking water in affected farms. These externalities due to sewage pollution was greatly influenced by the pollution intensity prevailed in affected lands. Thus the solution to the sewage pollution problem should consider the intensity of these externalities and hence appropriate strategies like proper functioning of Sewage 
Treatment Plants with recycling should be attempted specifically for the affected farms.

People's participation is necessary for the success of any scheme. 85.71 per cent of seriously affected farmers in the study area and 28.57 per cent of low affected farmers in study area are willing to pay or participate in schemes involved in tackling sewage pollution. Hence schemes to counter sewage pollution could be launched in the study area as the people's participation was very much evident in the study area and also in similar affected areas of the state. The contingent valuation technique employed in the study revealed the damage of seriously affected farmers at Rs.1800 per annum and Rs. 800 for low affected farmers. The sewage pollution problem is being existed in the area for more than 8 years and hence the compensation amount worked out to Rs. 14,400 using this time span for seriously affected farmers and Rs. 6400 for low affected farmers. The Government should pay this amount to the affected farmers as lump sum transfer until the problem is solved.

\section{REFERENCES}

[1] Abdalla, Charles W., Brain A. Roach and Donald J. Epp, 1992, Valuing Environmental Quality Changes Using Averting Expenditures: An Application to Groundwater Contamination, Land Economics, 68(2) : 163-169.

[2] Bariik, Timothy J., 1988 , "Evaluating the Benefits of Non-Marginal Reduction in Pollution using Information on Defensive Expenditures", Journal of Environmental Economics and Management, 15: 111-127.

[3] Briscoe, John; Paulo Furtado de Castro; Charles Griffin; James North; Orjan Olsen., 1990, "Toward Equitable and Sustainable Rural Water Supplies: A Contingent Valuation Studyin Brazil." The World Bank Economic Review, Volume: 4, Issue: 2, Pages: 115-134.

[4] Courant, Paul N. Richard and C. Porter,1981, "Averting Expenditure and the Cost of Pollution", Journal of Environmental Economics and Management, p. 3(4): 321-329.

[5] Cropper, L., Maureen and Wallace, E., Oates, 1992, "Environmental Economics: A Survey", Journal of Economic literature, p.30 (2):675-740.

[6] Jesu A., Prabudoss Kumar L. , Kandasamy K. and Dheenadayalan M.S., 2013, "Environmental Impact of Industrial Effluent in Vaigai River and the Ground Water in and around the River at Anaipatti of DindigulDistt, Tamil Nadu, India”, International
Research Journal of Environment Sciences, Vol. 2, No.4, Pg.34-38.

[7] Junaid Noor, WasifSiddiqi and Taj Muhammad, 2010, Estimation of Willingness to Pay for Improvements in Drinking Water Quality in Lahore: A Case Study of WASA, Lahore, University Library of Munich, Germany.

[8] LeenaHebsibai. L, Dheenadayalan. M.S andSivakumar . K.K, 2012, “An Assessment Study on the Quality of Industrial effluents in and around Vandiyur Lake, Madurai ,Tamil Nadu - India " , Journal of Chemical, Biological and Physical Sciences, Vol.2(3), pg.1556-1559.

[9] Mi-Jung Um, Seung- Jun kwak and Tai-Yookim,2002, "Estimating willingness to pay for improved drinking water quality using Averting behavior method with perception measure", Environmental and resource economics, 21: 287-302.

[10] MufeedSharholy, KafeelAhmad ,GauharMahmood and R.C. Trivedi, 2007, Municipal solid waste management in Indian cities - A review, Waste management, pp: 460- 467.

[11] Pattanayak.S.K., Yang.J.C., Whittington.D., Bal Kumar.K.C., 2005, "Coping with unreliable public water supplies: averting expenditures by households in Kathmandu, Nepal”, Water Resources Research, 41 (2).

[12]Rashmi Sharma., (2008), "Municipal Solid Waste Management in Ajmer City, Rajasthan",Nature Environment and Pollution Technology, 01 (4):pp639-642.

[13] Saravanan.P, Arun Prasad.K, Sudha.G, Ilangovan.P, (2011) "An assessment of environmental degradation: Case study of Avaniyapuram town panchayat, Madura i ,International Journal of

Environmental Sciences, Vol.1, No. 7, pg.1504-1514.

[14] Shadananan Nair (2010) "Challenges in urban water management in a changing environment - case study from a growing tropical city" ,Novatech Publications, pg. 1-7.

[15] SubhrendruK.Pattanayak. andJui-Chen Yang., "Coping with unreliable Public Water Supplies : Averting expenditures by Homeholds in Kathmandu, Nepal”, Water Resources Research, vol 41. 